\title{
Lavandulae aetheroleum Oil: A Review on Phytochemical Screening, Medicinal Applications, and Pharmacological Effects
}

\author{
Khaled Mohamed Mohamed Koriem 1,*(D) \\ 1 Department of Medical Physiology, Medical Research Division, National Research Centre, 33 El-Buhouth Street, Dokki, \\ Cairo, 12622, Egypt \\ * Correspondence: kkoriem@yahoo.com;
}

Scopus Author ID 24477156100

Received: 1.09.2020; Revised: 18.09.2020; Accepted: 19.09.2020; Published: 22.09.2020

\begin{abstract}
Lavandulae aetheroleum, the oil, was obtained by vapor condensation from the flower of Lavandula angustifolia Mill. or Lavandula intermedia Loisel (Lamiaceae) plant. Other names of Lavandulae aetheroleum oil are Al birri, common or English lavender. The Lavandula angustifolia Mill. or Lavandula intermedia Loisel plant is spreading in the Mediterranean, southern Europe, Bulgaria, Russia, and USA. The Lavandula angustifolia Mill. or Lavandula intermedia Loisel plant, is an odor shrub with 1-2 $\mathrm{m}$ in height. The oil is a clear, colorless, or pale yellow. The gas chromatography studies reported the following percentage of the major chemical constituents in the oil: linalyl acetate (25-46\%), linalool (20-45\%), terpinen-4-ol (1.2-6.0\%), lavendulyl acetate $(>1.0 \%), 1,8$-cineole $(1,8-$ cineol, cineol, cineole, eucalyptol) $(<2.5 \%)$, 3-octanone $(<2.5 \%)$, camphor $(<1.2 \%)$, limonene $(<$ $1.0 \%$ ), and $\alpha$-terpineol $(<2.0 \%)$. Medicinal applications of the oil include the treatment of restlessness, anxiety, cardiovascular disorders, insomnia, and gastrointestinal disorders, burns, diarrhea, headache, sore throats, and wounds. Pharmacological effects include experimental and clinical pharmacology. Experimental pharmacology includes anesthetic, anticonvulsant, sedative, anti-inflammatory, antimicrobial, antispasmodic, antispasmodic, central nervous system depressant effects. Clinical pharmacology includes anxiolytic, analgesic, and cardiovascular effects. The oil dose by inhalation = $0.06-0.2 \mathrm{ml} / 3$ times/day while oil dose internally $=1-4$ drops approximately $20-80 \mathrm{mg}$ on a sugar cube per day. In conclusion, Lavandulae aetheroleum oil had an anesthetic, anticonvulsant, sedative, antiinflammatory, antimicrobial, antispasmodic, antispasmodic, central nervous system depressant, anxiolytic, analgesic, and cardiovascular effects.
\end{abstract}

Keywords: Lavandulae aetheroleum; Lamiaceae; Constituents; Pharmacology; Dose.

(C) 2020 by the authors. This article is an open-access article distributed under the terms and conditions of the Creative Commons Attribution (CC BY) license (https://creativecommons.org/licenses/by/4.0/).

\section{Introduction}

Lavandulae aetheroleum was obtained by vapor condensation from the flower of Lavandula angustifolia Mill. or Lavandula intermedia Loisel (Lamiaceae) plant [1-4]. Other names of Lavandulae aetheroleum oil were Al birri, alhucema, arvaneh, aspic, broad-leaved lavenda, common lavender, Echter Lavendel, English lavender, espi, espic, espliego commun, firigla, frigous, garden lavendar, grando, hanan, hanene, hzama, khazama, khirii, khouzamaa, khouzami, khuzama, khuzama fassiya, khuzama zerqua, Kleiner Speik, Lavanda, lavande, lavande femelle, lavande veritable, lavando, lavandula vraie, Lavendel, lavender, lawanda, lofinda, ostoghodous, postokhodous, spigandos, true lavender [5-10]. The Lavandula angustifolia Mill. or Lavandula intermedia Loisel plant extended through north regions of the https://biointerfaceresearch.com/ 
Mediterranean. It also occurred in southern Europe and in Bulgaria, Russia, the USA, and the former Yugoslavia regions [6, 11]. The Lavandula angustifolia Mill. or Lavandula intermedia Loisel plant is defined as a shrub with 1-2 $\mathrm{m}$ in height. The leaves varied from grey-brown to dark brown. The plant had a long flower. Leaves arranged on leafy shoots with widely spaced shoots. The plant had very short petiole while the blade ranged from lanceolate to linear with $17 \mathrm{~mm}$ long, $2 \mathrm{~mm}$ wide, $2-6 \mathrm{~cm}$ long. The plant had grey stellate, base attenuate, margin entire, revolute, apex obtuse. Inflorescence defined as crowded with 2-8 cm long and 6-10 flowers [6]. The Lavandula angustifolia Mill. plant extended in Kirklareli and Edirne provinces in Turkey [12]. The Lavandula angustifolia Mill. plant had a huge and significant influence in the world economy due to its incorporation in perfumes, cosmetics, food industrialized, aromatherapy, and pharmaceutical industries [13]. The smell of Lavandulae aetheroleum oil obtained from Lavandula angustifolia Mill. plant enhanced sleep quality and quantity, quality of life, and mood in diabetic patients with restlessness states without any effect on metabolic status [14]. The Lavandula angustifolia Mill plant had a similar effect to fluoxetine (antidepressant drug) to treat mild to moderate depression [15]. In another in-vitro and in-vivo research, the Lavandula intermedia Loisel plant caused a prospective defense product on different nematodes [16]. The Lavandula intermedia Loisel plant had been applied to be natural herbicide, which totally stops the seed growth of Raphanus sativus [17].

\section{Characteristics of the oil}

The oil had clear, colorless, or pale yellow fluid, miscible with $90 \%$ alcohol, ether, and fatty oils [1-4]. The oil odor had specific, perfumed, and aromatic, while the oil with a slightly bitter taste $[1,3]$.

\section{Chemical properties of the oil}

The oil relative density $=0.878-0.892$. The refractive index $=1.455-1.466$. The acid content in the oil does not exceed 1.0 [4].

\section{Chemical constituents of the oil}

The gas chromatography application proved the following 10 constituents in the oil: (1) limonene, (2) cineole, (3) 3-octanone, (4) camphor, (5) linalool, (6) linalyl acetate, (7) terpinen4-ol, (8) lavandulyl acetate, (9) lavandulol and (10) $\alpha$-terpineol [4]. The chromatography analysis revealed that the chemical composition of the oil contains carvacrol (65.27\%) as the most major constituent in Lavandula species distributed widely in the Dead Sea Valley, Palestine [18].

\section{Percentage of oil major chemical constituents}

The gas chromatography studies reported the following percentage of the major chemical constituents in the oil: linalyl acetate (25-46\%), linalool (20-45\%), terpinen-4-ol (1.2$6.0 \%)$, lavendulyl acetate $(>1.0 \%), 1,8$-cineole $(1,8$-cineol, cineol, cineole, eucalyptol) $(<$ $2.5 \%)$, 3-octanone $(<2.5 \%)$, camphor $(<1.2 \%)$, limonene $(<1.0 \%)$, and $\alpha$-terpineol $(<2.0 \%)$ [4]. 


\section{Medicinal applications}

Lavandulae aetheroleum oil used in the treatment of restlessness, anxiety and the oil caused relaxation [19-23]. It is also used for the treatment of cardiovascular disorders [24, 25]. The oil is applied in the treatment of insomnia and in the treatment of gastrointestinal disorders $[26,27]$. In folklore medicine, it is used as a cholagogue, diuretic, and emmenagogue agents, and the oil also used in the treatment of burns, diarrhea, headaches, sore throats, and wounds [26]. The oil declined the restless legs syndrome in hemodialysis patients, where the oil was effective in decreasing the restless legs syndrome by the application of oil massage [28]. The oil declined the quail's liver weights. The oil also ameliorated the $\mathrm{pH}$, water content, and fat content of the quail's meat. The oil decreased the endogenous intestinal population of Lactobacillus, and the bacteria (such as Escherichia coli and Staphylococcus aureus). Consequently, the supplementing of quail with Lavandulae aetheroleum oil has a beneficial effect on quail growth and antimicrobial effects [29].

\section{Pharmacology of the oil}

\subsection{Experimental pharmacology.}

\subsubsection{Anesthetic effect.}

The oil or its major constituents (linalyl acetate or linalool) in the in-vitro study at a dose of $0.01-10.0 \mu \mathrm{g} / \mathrm{ml}$ declined animal diaphragm. Also, the oil or its major constituents (linalyl acetate or linalool) in an in-vivo study at a dose ranged from $30.0-2500.0 \mu \mathrm{g} / \mathrm{ml}$ increased the number of stimuli needed to inflame the reflex [30]. The oil declined senses buried numbers. The oil also amplified time spent and entries number ratios into the open arms compared with control. No effect was seen in closed arm entries or beam interruptions ratios [31]. In Germany, the oil is approved for restlessness therapy in an anxious mood where the oil has a benzodiazepine-like effect [32]. The oil decreased the levels of pain severity in postoperative pain after inguinal hernia surgery. This study includes 90 participants in 4 stages of measurements. So, the oil decreased post-operative pain after inguinal hernia surgery [33]. The Lavandulae aetheroleum oil massage was effective in the control of painful temporomandibular disorders situations and narrow mouth opening [34].

\subsubsection{Anticonvulsant and sedative effects.}

Injection with $2.5 \mathrm{~g} / \mathrm{kg}$ body weight (bw) of linalool protected against convulsions caused by pentylenetetrazole, picrotoxin, and electroshock $[35,36]$. The injection of $2.5 \mathrm{~g} / \mathrm{kg}$ bw of linalool obstructed glutamate function and postponed $N$-methyl-d-aspartate-induced convulsions [37]. Linalool counteracts [3H]-glutamate and [3H]-dizocilpine in animal membranes and consequently counteract glutamatergic transmission. Linalool also declined potassium-stimulated glutamate discharge. In conclusion, linalool counteracts with components of the excitatory glutamatergic transmission system [38]. Linalool caused sedation at a dose of $25 \mathrm{mg} / \mathrm{L}$ and anesthesia with a dose of 50-100 mg/L, but linalool did not change acetylcholinesterase level in the muscle and brain, so linalool did not effect in gammaaminobutyric acid antagonist (GABAA) receptors in both muscle and brain [39]. Linalool possessed an obvious antidepressant effect where the standard concentration equal to $97.0 \%$ [40]. Linalool (at a dose of $0.8 \mathrm{ml} / \mathrm{kg}$ ) completely stopped pentylenetetrazol-caused 
convulsions with sedative effect [41]. Linalool declined squares crossed, escapes, defecation, and distress call numbers while jumped sleeping position, and this related to the sedative effect of linalool [42]. In a clinical study, the oil declined the tooth pain levels in children by inhalation with the oil. This study was done on 126 children age (6-12 years). At the same time, the oil declined the anxiety level in those children [43]. The Lavandulae aetheroleum oil declined the daytime sleeping, and this result was shown by decreasing the daytime sleeping scores on the scales applied, and this observation refers to decline sleepiness [44]. The oil declined the pain level in the group, which had an oil massage protocol. The oil massage decreased post-operative pain after gynecologic surgery. The oil had a longer effect in decreasing post-operative pain. Consequently, the oil had an inexpensive and easy-to-apply method was done by nurses on post-operative patients [45]. The oil declined the extubation time, surgical site pain severity, and anxiety in patients experiencing open-heart surgery [46]. The smell of the Lavandulae aetheroleum oil increased sleep quality and quality of life in women with sleep deficiency problems during menopause [47].

\subsubsection{Anti-inflammatory effect.}

Aqueous solutions of Lavandulae aetheroleum oil (1:500, 1:100, 1:10, 1:1, and 1:0) decreased mast cell-dependent ear edema. These doses of Lavandulae aetheroleum oil aqueous solutions declined cutaneous anaphylaxis caused by antidinitrophenyl IgE compound (which caused histamine secretion) and anti-antidinitrophenyl IgE compound (which caused tumor necrosis factor- $\alpha$ secretion) from peritoneal mast cells [48]. In other research, $0.3 \mathrm{ml}$ of Lavandulae aetheroleum decreased thromboxane B2 secretion stimulated by arachidonic acid, so the oil has an anti-inflammatory effect [49]. Lavandulae aetheroleum oil improved the depression-like behavior. The oil possessed a neurogenic effect where the oil enhanced neurogenesis and dendritic complexity. The oil also improved serum oxytocin levels [50]. The inflammatory response was declined by animal treatment with oil. However, the oil possessed an anti-edematogenic effect, and it inhibited spontaneous nociception [51]. The oil also declined allergic inflammation and mucous cell hyperplasia and decreased T-helper- 2 cell cytokines and RNA expression of cytokines and mucin in lung tissue in asthma. So, Lavandulae aetheroleum oil is a good alternative medicine for bronchial asthma [52]. The antiinflammatory effect of oil is similar to the anti-inflammatory effect of Oleum azadirachti oil [53]. The oil stopped Phytohemagglutinin-caused tryptophan break and kynurenine creation. So, the oil declined neopterin and interferon- $\gamma$ synthesis [54]. The oil exhibited $73.67 \%$ recovery in the psoriasis area severity index and $87 \%$ in Thymus-17 cytokines. The 2 major constituents of the oil (linalool and linalyl acetate) showed $64 \%$ and $47.61 \%$ recovery in psoriasis area severity index scores. The linalool and linalyl acetate recovered Thymus- 1 tumor necrosis factor- $\alpha$ and interleukin- $1 \beta$. The linalool recovered Thymus-17 cytokines (interleukin17 and interleukin-22) [55].

\subsubsection{Antimicrobial effect.}

Lavandulae aetheroleum oil in in-vitro research declined Bacillus subtilis, Escherichia coli, Pseudomonas aeruginosa, Staphylococcus aureus, and Streptococcus pneumoniae growth $[56,57]$. The oil at a dose of $10.0 \mu \mathrm{l}$ decreased Mycobacterium chelonae, M. fortuitum, M. kansasii, M. marinum, and M. scrofulaceum growth [58]. In another in-vitro study, the oil declined filamentous fungi growth [59]. The oil, besides its major constituents (linalool, linalyl 
acetate, and camphor), possessed a miticidal effect against Psoroptes cuniculi [60]. The oil showed a higher effect on both bacilli types (Gram-positive and Gram-negative), but the oil did not inhibit the growth of Gram-positive cocci. The oil declined the mixed microbiota cell number from facial skin [61]. The oil possessed an antimicrobial effect [62]. The oil improved an anxiety state in patients, and also the oil has an obvious effect in the Pittsburgh Quality Sleep Index measurements [63]. The oil at a dose of $100 \mathrm{mg} / \mathrm{kg}$ recovers the cognitive performance of animal behavior scopolamine. The oil declined the acetylcholinesterase and malondialdehyde levels while increases superoxide dismutase and glutathione levels. The oil declined lactate dehydrogenase and nitric oxide secretion, intracellular reactive oxygen species production, and mitochondrial membrane potential activities [64]. The oil reduced donkey louse (Bovicola ocellatus) parasites intensity, and the reduction rate was equal to 78\% [65]. In a clinical study, about 300 patients treated with the oil exhibited major symptom scores in acute viral rhinosinusitis and showed an increase in the quality of life. Consequently, oil treatment declined all the signs of acute viral rhinosinusitis in adult patients [66]. In other clinical trials, about 260 patients with acute bronchitis, the oil ameliorates the viral symptoms and improve life safety. So, oil is effective in treating severe viral symptoms in adult patients [67]. The oil possessed strong antioxidant, antiacetylcholinesterase, antibutyrylcholinesterase, and antilipase activities. The oil also had a strong antidermatophyte effect against Trichophyton rubrum, Microsporum canis, Trichophyton mentagrophytes, and Epidermophyton floccosum. The high antioxidant, enzyme inhibitory, and antimicrobial effects of the oil-related to its high monoterpenes content (carvacrol) [14].

\subsubsection{Antispasmodic effect.}

The aqueous doses $(0.02 \mathrm{mg} / \mathrm{ml}$ and $0.2 \mathrm{mg} / \mathrm{ml})$ of Lavandulae aetheroleum oil declined the animal contracting response and relaxed the animal muscle tone in in-vitro research [68]. The antispasmodic effect of the oil and its major constituent (linalool) was controlled by cyclic adenosine monophosphate signal transduction system in animal ileum smooth muscle preparation [69]. The oil declined phyto-hemagglutinin-caused tryptophan break and kynurenine creation. Also, the oil decreased neopterin and interferon- $\gamma$ levels [70]. The oil inhalation improved brainwaves in the electroencephalogram instrument, and this effect was stable for the oil, and the oil amended the patients' questionnaire results [71]. The oil showed antioxidant and antimicrobial effects [72]. The oil revealed a cytotoxic effect against Ichthyophthirius multifiliis group compared to control in the in-vitro study [73]. The oil served as antibiotic resistance modifying agent and consequently declined antibiotics application and so declined the antibiotics adverse effects and counteracted the beta-lactam antibiotic resistance [74]. In a clinical study, 7 adult males with an age range from 20-40 years old. The oil smell declined depression score. In the same study, the in-vivo study showed that the oil administration increased intracellular $\mathrm{Ca}^{2+}$ levels in the hypothalamic oxytocin neurons. Consequently, oil is a useful treatment in stress relief. The oil mechanism includes stimulation of the central oxytocin neurons [75].

\subsubsection{Central nervous system depressant effect.}

Lavandulae aetheroleum oil declined caffeine-caused hyperactivity, and this effect was associated with linalool serum levels [70]. The oil caused anxiolytic effects and continued pentobarbital sleeping time [76]. The dose of $1.6 \mathrm{~g} / \mathrm{kg}$ bw of the oil jumped the animal lever- 
pressing response rate during the alarm phase, which related to the anti-conflict effect of the oil, which the same as diazepam [77]. In another research, the oil at a dose of $25.0 \mathrm{ml} / \mathrm{kg}$ bw increased pentobarbital sleeping times [78]. The oil at a dose of $0.3 \mathrm{ml}$ declined strychninecaused animal convulsions [48]. The oil at daily doses of 80 or $160 \mathrm{mg}$ possessed an improved action on anxiety disorders such as diminished sleep, somatic illnesses, prolonged depression, or decreased life ability $[79,80]$.

\subsection{Clinical pharmacology.}

\subsubsection{Anxiolytic effect.}

In clinical research where 40 patients received Lavandulae aetheroleum oil, the electroencephalogram caused a jump in beta power, so the oil possessed drowsiness. The patients taken Lavandulae aetheroleum oil revealed lower depression and higher relaxation and accomplished the mathematical processes more perfectly [20]. In another clinical study, Lavandulae aetheroleum oil declined serum alpha-1 (8-10 Hertz), and the patients feel "pleased" [22].

In clinical research, patients are exposed to either massage or Lavandulae aetheroleum oil (1-3 treatments through a 5-day period) or a period of rest to evaluate different factors on the stress response and anxiety. In the stress response, no difference was found between the three above mentioned factors. The patients taken Lavandulae aetheroleum oil found an improvement in mood and a decline of anxiety [81]. In other clinical studies, patients with chronic hemodialysis, Lavandulae aetheroleum oil through a one-week period, declined the mean score in the Hamilton anxiety rating scale [21]. The oil has a good effect on anxiety and its physiological indices [82], although, in another clinical trial, 1 hour of inhalation of $0.1-\mathrm{mL}$ and $0.3-\mathrm{mL}$ of the oil in $120 \mathrm{~mL}$ of water did not have an anxiolytic effect on patients experiencing orthognathic surgery [83]. In another clinical study, the oil applies a secondary sleep improving effect by its anxiolytic action rather than by sedation [84]. In a clinical study, the oil declined the anxiety after the inhalation with the oil. The oil declined respiration and increased oxygen saturation. Consequently, the oil declined anxiety and its major symptoms in benign prostate hyperplasia patients [85]. The oil decreased the mean scores of the nurse's anxiety by $37.82 \%$. On the other hand, the combination of music therapy and oil therapy delined the mean scores of the nurse's anxiety by $40.03 \%$.

Consequently, music therapy and Lavandulae aetheroleum oil declined the anxiety of nurses in the clinical setting, which affect their professional performance [86]. In another clinical study, the bone marrow biopsy is correlated with anxiety. The oil inhalation is effective in declining the anxiety in these patients. This oil is used for the treatment of the hematology and oncology symptoms in this disease to decline anxiety induced by bone marrow biopsy [87]. The smell of the Lavandulae aetheroleum oil declined pain and anxiety. The oil amended patient relaxation without affecting the saliva cortisol level in myofascial pain syndrome patients [88]. The oil improved preoperative anxiety. The oil was applied by (1) inhalation, (2) oil massage, and (3) oral administration were effective. The oil showed a better effect on preoperative anxiety. So, The oil was effective in reducing preoperative anxiety in adults. The oil inhalation was to be more effective in clinical trials [89]. 


\subsubsection{Analgesic effect.}

In a clinical study, Lavandulae aetheroleum oil in baby bathwater daily for 10 days after childbirth did not decline the perineal discomfort rate [90]. In another clinical research, Lavandulae aetheroleum oil or synthetic lavender oil in a baby water bath for 10 days after childbirth revealed no change between these 2 oil treatments in the declined of perineal discomfort [91]. The oil possessed an analgesic effect besides its antioxidant and antiinflammatory effects $[51,92]$. The oil showed an obvious decline in daily acetaminophen usage in post-operative days in pediatric patients but had not any effect on pain strength and night arousal [93]. The analgesic effect of oil is very similar to the sedative effect of Anisi aetheroleum oil [94]. In a clinical study on palliative care patients, the oil had no effect on the major symptoms of the patients. At the same time, the oil caused a deeper sleep on the $2^{\text {nd }}$ day after oil administration. The oil enabled patients to fall asleep and sleeping again when they were aroused. The oil improved sleep quality. The oil declined the arousal regularity on the $1^{\text {st }}$ and $2^{\text {nd }}$ days-the oil improved overall sleep quality after oil administration [95]. In a clinical study, 90 patients participated in the study, and the results found that the oil was decreased pain and anxiety levels of the patients while patients' oxygen saturation levels were increased [96]. In another study, 59 elderly individuals were applied in this study procedure. The oil administration amended the sleep quality and decreased fatigue severity in the elderly [97].

\subsubsection{Cardiovascular effect.}

In a clinical study, Lavandulae aetheroleum oil in a foot water bath for 10 minutes increased parasympathetic nerve action and improved blood circulation but without any effect on cardiac or respiratory rates [24]. The oil prompts olfactory in stroke patients with anxiety, which inflated diastolic blood pressure with higher levels of characteristic anxiety symptoms [98]. The Lavandulae aetheroleum oil was declined systolic and diastolic blood pressure. The oil ameliorated the pulse rate of the heart, systolic and diastolic blood pressure $[75,96]$

\section{Side Effect of the oil}

The allergy is the obvious side effect of the oil observed in patients previously exposed to Lavandulae aetheroleum oil [99-101]. Owing to allergy side effect of the oil, Lavandulae aetheroleum oil should not be applied during pregnancy $[102,103]$ and must keep away from children and must be used under the supervision of a specialist physician.

\section{Dosage of the oil}

The dose of Lavandulae aetheroleum oil by inhalation is equal to $0.06-0.2 \mathrm{ml} / 3$ times/day [104], while Lavandulae aetheroleum oil dose internally is equal to 1-4 drops approximately $20-80 \mathrm{mg}$ on a sugar cube per day [27].

\section{Conclusion}

Lavandulae aetheroleum, the oil, was obtained by vapor concentration from the flower of Lavandula angustifolia Mill. or Lavandula intermedia Loisel (Lamiaceae) plant. The oil is a clear, colorless, or pale yellow. The gas chromatography studies reported the following major chemical constituents in the oil: linalyl acetate (25-46\%), linalool (20-45\%), terpinen-4-ol (1.2- 
$6.0 \%)$, lavendulyl acetate $(>1.0 \%), 1,8$-cineole $(1,8$-cineol, cineol, cineole, eucalyptol) $(<$ $2.5 \%)$, 3-octanone $(<2.5 \%)$, camphor $(<1.2 \%)$, limonene $(<1.0 \%)$, and $\alpha$-terpineol $(<2.0 \%)$. Medicinal applications of the oil include the treatment of restlessness, anxiety, cardiovascular disorders, insomnia, and gastrointestinal disorders, burns, diarrhea, headaches, sore throats, and wounds. Pharmacological effects include experimental and clinical pharmacology. Experimental pharmacology includes anesthetic, anticonvulsant, sedative, anti-inflammatory, antimicrobial, antispasmodic, antispasmodic, central nervous system depressant effects. Clinical pharmacology includes anxiolytic, analgesic, and cardiovascular effects. The oil dose by inhalation is equal to $0.06-0.2 \mathrm{ml} / 3$ times/day, while the oil dose internally is equal to $1-4$ drops approximately $20-80 \mathrm{mg}$ on a sugar cube per day.

\section{Funding}

This research received no external funding.

\section{Acknowledgments}

This research has no acknowledgment.

\section{Conflicts of Interest}

The authors declare no conflict of interest.

\section{References}

1. Egyptian pharmacopoeia. $3^{\text {rd }}$ ed. Cairo, General Organization for Government Printing, 1972.

2. Ekstra Farmakope Indonesia. Jakarta, Departemen Kesehatan, Republik Indonesia, 1974.

3. Asian crude drugs, their preparations and specifications. Asian pharmacopoeia. Manila, Federation of Asian Pharmaceutical Associations, 1978.

4. European pharmacopoeia. $3^{\text {rd }}$ ed. Suppl. Strasbourg, Council of Europe, 2001.

5. African pharmacopoeia. Lagos, Nigeria, Organization of African Unity, Scientific Technical and Research Commission, Volume 1, 1986.

6. Oyen, L.P.A.; Nguyen, X.D. Plant resources of South-east Asia, No. 19. Essential-oil plants. Bogor, PROSEA 1999.

7. Bejeuhr, G. Hager's handbook of pharmaceutical practice. Pharm Unserer Zeit 1995, 24, 81-84, https://doi.org/10.1002/pauz.19950240209.

8. Zahedi, E. Botanical dictionary. Scientific names of plants in English, French, German, Arabic and Persian languages. Tehran, Tehran University Publications, 1959.

9. Schlimmer, J.L. Terminologie médico-pharmaceutique et française-persane. $2^{\text {nd }}$ ed. [French-Persian medico-pharmaceutical terminology, $2^{\text {nd }}$ ed. Tehran, University of Tehran Publications, 1979.

10. Bellakhdar, J.; Claisse, R.; Fleurentin, J.; Younos, C. Repertory of standard herbal drugs in the Moroccan harmacopoeia. J Ethnopharmacol 1991, 35, 123-143, https://doi.org/10.1016/0378-8741(91)90064-K.

11. Bisset, N.G. Herbal drugs and phytopharmaceuticals. Boca Raton, FL, CRC Press, 1994.

12. Özalp, T.; Könül, G.; Ayyıldı,, Ö.; Tülek, A.; Devran, Z. First report of root-knot nematode, Meloidogyne arenaria, on lavender in Turkey. J Nematol 2020, 52, 1-3, https://doi.org/10.21307/jofnem-2020-008.

13. Demasi, S.; Caser, M.; Lonati, M.; Cioni, P.L.; Pistelli, L.; Najar, B.; Scariot, V. Latitude and Altitude Influence Secondary Metabolite Production in Peripheral Alpine Populations of the Mediterranean Species Lavandula angustifolia Mill. Front Plant Sci 2018, 9, https://doi.org/10.3389/ffpls.2018.00983.

14. Nasiri Lari, Z.; Hajimonfarednejad, M.; Riasatian, M.; Abolhassanzadeh, Z.; Iraji, A.; Vojoud, M.; Heydari, M.; Shams, M. Efficacy of inhaled Lavandula angustifolia Mill. Essential oil on sleep quality, quality of life and metabolic control in patients with diabetes mellitus type II and insomnia. J Ethnopharmacol 2020, 251, https://doi.org/10.1016/j.jep.2020.112560.

15. Araj-Khodaei, M.; Noorbala, A.A.; Yarani, R.; Emadi, F.; Emaratkar, E.; Faghihzadeh, S.; Parsian, Z.; Alijaniha, F.; Kamalinejad, M.; Naseri, M. A double-blind, randomized pilot study for comparison of Melissa officinalis L. and Lavandula angustifolia Mill. with fluoxetine for the treatment of depression. BMC Complement Med Ther 2020, 20, https://doi.org/10.1186/s12906-020-03003-5. 
16. Andrés, M.F.; González-Coloma, A.; Muñoz, R.; De la Peña, F.; Julio, L.F.; Burillo, J. Nematicidal potential of hydrolates from the semi industrial vapor-pressure extraction of Spanish aromatic plants. Environ Sci Pollut Res Int 2018, 25(30): 29834-29840, https://doi.org/10.1007/s11356-017-9429-z.

17. Politi, M.; Menghini, L.; Conti, B.; Bedini, S.; Farina, P.; Cioni, P.L.; Braca, A.; De Leo, M. Reconsidering hydrosols as main products of aromatic plants manufactory: the Lavandin ( Lavandula intermedia) case study in Tuscany. Molecules 2020, 25, https://doi.org/10.3390/molecules25092225.

18. Ali-Shtayeh, M.S.; Abu-Zaitoun, S.Y.; Dudai, N.; Jamous, R.M. Downy Lavender Oil: A Promising Source of Antimicrobial, Antiobesity, and Anti-Alzheimer's Disease Agents. Evid Based Complement Alternat Med 2020, 2020, https://doi.org/10.1155/2020/5679408.

19. Dunn, C.; Sleep, J.; Collett, D. Sensing an improvement: an experimental study to evaluate the use of aromatherapy, massage and periods of rest in an intensive care unit. J Adv Nurs 1995, 21, 34-40, https://doi.org/10.1046/j.1365-2648.1995.21010034.x.

20. Diego, M.A.; Jones, N.A.; Field, T.; Hernandez-Reif, M.; Schanberg, S.; Kuhn, C.; McAdam, V.; Galamaga, R.; Galamaga, M. Aromatherapy positively affects mood, EEG patterns of alertness and math computations. Int J Neurosci 1998, 96, 217-724, https://doi.org/10.3109/00207459808986469.

21. Itai, T.; Amayasu, H.; Kuribayashi, M.; Kawamura, N.; Okada, M.; Momose, A.; Tateyama, T.; Narumi, K.; Uematsu, W.; Kaneko, S. Psychological effects of aromatherapy on chronic hemodialysis patients. Psychiatry Clin Neurosci 2000, 54, 393-7, https://doi.org/10.1046/j.1440-1819.2000.00727.x.

22. Masago, R.; Matsuda, T.; Kikuchi, Y.; Miyazaki, Y.; Iwanaga, K.; Harada, H.; Katsuura, T. Effect of inhalation of essential oils on EEG activity and sensory evaluation. J Physiol Anthropol Appl Human Sci 2000, 19, 35-42, https://doi.org/10.2114/jpa.19.35.

23. Sayed, A. M.; Morsy, S.; Tawfik, G.M.; Naveed, S.; Minh-Duc, N.T.; Hieu, T.H.; Ali, Z.A.; Shinkar, A.; Doheim, M.F.; Hashan, M.R.; Huy, N.T. The best route of administration of lavender for anxiety: a systematic review and network meta-analysis. Gen Hosp Psychiatry 2020, 64, 33-40, https://doi.org/10.1016/j.genhosppsych.2020.02.001.

24. Saeki, Y. The effect of foot-bath with or without the essential oil of lavender on the autonomic nervous system: a randomized trial. Complement Ther Med 2000, 10, 2-7, https://doi.org/10.1016/S09624562(00)80011-9.

25. Seol, G.H.; Lee, Y.H.; Kang, P.; You, J.H.; Park, M.; Min, S.S. Randomized controlled trial for Salvia sclarea or Lavandula angustifolia: differential effects on blood pressure in female patients with urinary incontinence undergoing urodynamic examination. $J$ Altern Complement Med 2013, 19 664-670, https://doi.org/10.1089/acm.2012.0148.

26. Bisset, N.G. Herbal drugs and phytopharmaceuticals. Boca Raton, FL, CRC Press, 1994.

27. Blumenthal, M.; Busse, W.R.; Goldberg, A.; Gruenwald, J.; Hall, T.; Riggins, C.W. The complete German Commission E monographs. Austin, TX, American Botanical Council, 1998.

28. Mirbagher Ajorpaz, N.; Rahemi, Z.; Aghajani, M.; Hashemi, S.H. Effects of glycerin oil and lavender oil massages on hemodialysis patients' restless legs syndrome. J Bodyw Mov Ther 2020, 24, 88-92, https://doi.org/10.1016/j.jbmt.2019.06.012.

29. Laghouati O, Arbouche F, Arbouche Y. Effects of using essential oil of Lavandula stoechas in quail feed on growth performance, carcass characteristics, meat quality, and health status. Vet World 2019, 13, 789-795, https://doi.org/10.14202/vetworld.2020.789-795.

30. Ghelardini, C.; Galeotti, N.; Salvatore, G.; Mazzanti, G. Local anaesthetic activity of the essential oil of Lavandula angustifolia. Planta Med 1999, 65, 700-703, https://doi.org/10.1055/s-1999-14045.

31. Chioca, L.R.; Ferro, M.M.; Baretta, I.P.; Oliveira, S.M.; Silva, C.R.; Ferreira, J.; Losso, E.M.; Andreatini, R. Anxiolytic-like effect of lavender essential oil inhalation in mice: participation of serotonergic but not GABAA/benzodiazepine neurotransmission. $J$ Ethnopharmacol 2013, 147, 412-418, https://doi.org/10.1016/j.jep.2013.03.028.

32. Silenieks, L.B.; Koch, E.; Higgins, G.A. Silexan, an essential oil from flowers of Lavandula angustifolia, is not recognized as benzodiazepine-like in rats trained to discriminate a diazepam cue. Phytomedicine 2013, 20, 172-177, https://doi.org/10.1016/j.phymed.2012.10.004.

33. Bagheri, H.; Salmani, T.; Nourian, J.; Mirrezaie, S.M.; Abbasi, A.; Mardani, A.; Vlaisavljevic, Z. The Effects of Inhalation Aromatherapy Using Lavender Essential Oil on Postoperative Pain of Inguinal Hernia: A Randomized Controlled Trial. J Perianesth Nurs 2020, 21, https://doi.org/10.1016/j.jopan.2020.03.003.

34. Benli, M.; Olson, J.; Huck, O.; Özcan, M. A novel treatment modality for myogenous temporomandibular disorders using aromatherapy massage with lavender oil: A randomized controlled clinical trial. Cranio 2020, 1-11, https://doi.org/10.1080/08869634.2020.1819067.

35. Elisabetsky, E; Marschner, J.; Souza, D.O. Effects of Linalool on glutamatergic system in the rat cerebral cortex. Neurochem Res 1995, 20, 461-465, https://doi.org/10.1007/bf00973103.

36. Elisabetsky, E.; Silva Brum, L.F.; Souza, D.O. Anticonvulsant properties of linalool on glutamate-related seizure models. Phytomedicine 1999, 6, 107-113, https://doi.org/10.1016/s0944-7113(99)80044-0.

37. Brum, L.F.; Elisabetsky, E.; Souza, D. Effects of linalool on $[3 \mathrm{H}] \mathrm{MK} 801$ and $[3 \mathrm{H}]$ muscimol binding in mice cortical membranes. Phytother Res 2001, 15, 422-425, https://doi.org/10.1002/ptr.973. 
38. Silva Brum, L.F.; Emanuelli, T.; Souza, D.O.; Elisabetsky, E. Effects of linalool on glutamate release and uptake in mouse cortical synaptosomes. Neurochem Res 2001, 26, 191-194, https://doi.org/10.1023/a:1010904214482.

39. Bianchini, A.E.; Garlet, Q.I.; da Cunha, J.A.; Junior B.G.; Brusque, I.C.M.; Salbego, J.; Heinzmann, B.M.; Baldisserotto, B. Monoterpenoids (thymol, carvacrol and S-(+)-linalool) with anesthetic activity in silver catfish (Rhamdia quelen): evaluation of acetylcholinesterase and GABAergic activity. Braz J Med Biol Res 2017, 50, https://doi.org/10.1590/1414-431x20176346.

40. Dos Santos, É.R.Q.; Maia, C.S.F.; Fontes Junior, E.A.; Melo, A.S.; Pinheiro, B.G.; Maia, J.G.S. Linaloolrich essential oils from the Amazon display antidepressant-type effect in rodents. J Ethnopharmacol 2018, 212, 43-49, https://doi.org/10.1016/j.jep.2017.10.013.

41. Rakotosaona, R.; Randrianarivo, E.; Rasoanaivo, P.; Nicoletti, M.; Benelli, G.; Maggi, F. Effect of the leaf essential oil from Cinnamosma madagascariensis Danguy on pentylenetetrazol-induced seizure in rats. Chem Biodivers 2017, 14, 1-5, https://doi.org/10.1002/cbdv.201700256.

42. Gastón, M.S.; Cid, M.P.; Vázquez, A.M.; Decarlini, M.F.; Demmel, G.I.; Rossi, L.I.; Aimar, M.L.; Salvatierra, N.A. Sedative effect of central administration of Coriandrum sativum essential oil and its major component linalool in neonatal chicks. Pharm Biol 2016, 54, 1954-1961, https://doi.org/10.3109/13880209.2015.1137602.

43. Arslan, I.; Aydinoglu, S.; Karan, N.B. Can lavender oil inhalation help to overcome dental anxiety and pain in children? A randomized clinical trial. Eur J Pediatr 2020, 179, 985-992, https://doi.org/10.1007/s00431020-03595-7.

44. Aydın Yıldırım, T.; Kitiş, Y. The effect of aromatherapy application on cognitive functions and daytime sleepiness in older adults living in a nursing home. Holist Nurs Pract 2020, 34, 83-90, https://doi.org/10.1097/HNP.0000000000000371.

45. Mizrak Sahin, B.; Culha, I.; Gursoy, E.; Yalcin, O.T. Effect of Massage With Lavender Oil on Postoperative Pain Level of Patients Who Underwent Gynecologic Surgery: A Randomized, Placebo-Controlled Study. Holist Nurs Pract 2020, https://doi.org/10.1097/HNP.0000000000000400.

46. Babatabar Darzi, H.; Vahedian-Azimi, A.; Ghasemi, S.; Ebadi, A.; Sathyapalan, T.; Sahebkar, A. The effect of aromatherapy with rose and lavender on anxiety, surgical site pain, and extubation time after open-heart surgery: A double-center randomized controlled trial. Phytother Res 2020, https://doi.org/10.1002/ptr.6698.

47. Gürler, M.; Kızılırmak, A.; Baser, M. The Effect of Aromatherapy on Sleep and Quality of Life in Menopausal Women with Sleeping Problems: A Non-Randomized, Placebo-Controlled Trial. Complement Med Res 2020, 1-10, https://doi.org/10.1159/000507751.

48. Kim, H.M.; Cho, S.H. Lavender oil inhibits immediate-type allergic reaction in mice and rats. J Pharm Pharmacol 1999, 51 221-226, https://doi.org/10.1211/0022357991772178.

49. Yamada, K.; Mimaki, Y.; Sashida, Y. Anticonvulsive effects of inhaling lavender oil vapour. Biol Pharm Bull 1994, 17, 359-360, https://doi.org/10.1248/bpb.17.359.

50. Sánchez-Vidaña, D.I.; Po, K.K.; Fung, T.K.; Chow, J.K.; Lau, W.K.; So, P.K.; Lau, B.W.; Tsang, H.W. Lavender essential oil ameliorates depression-like behavior and increases neurogenesis and dendritic complexity in rats. Neurosci Lett 2019, 701, 180-192, https://doi.org/10.1016/j.neulet.2019.02.042.

51. Silva, G.L.; Luft, C.; Lunardelli, A.; Amaral, R.H.; Melo, D.A.; Donadio, M.V.; Nunes, F.B.; de Azambuja, M.S.; Santana, J.C.; Moraes, C.M.; Mello, R.O.; Cassel, E.; Pereira, M.A.; de Oliveira, J.R. Antioxidant, analgesic and anti-inflammatory effects of lavender essential oil. An Acad Bras Cienc 2015, 87, 1397-1408, https://doi.org/10.1590/0001-3765201520150056.

52. Ueno-Iio, T.; Shibakura, M.; Yokota, K.; Aoe, M.; Hyoda, T.; Shinohata, R.; Kanehiro, A.; Tanimoto, M.; Kataoka, M. Lavender essential oil inhalation suppresses allergic airway inflammation and mucous cell hyperplasia in a murine model of asthma. Life Sci 2014, 108, 109-115, https://doi.org/10.1016/j.lfs.2014.05.018.

53. Koriem, K.M. Review on pharmacological and toxicologyical effects of oleum azadirachti oil. Asian Pac J Trop Biomed 2013, 3, 834-840, https://doi.org/10.1016/S2221-1691(13)60165-3.

54. Gostner, J.M.; Ganzera, M.; Becker, K.; Geisler, S.; Schroecksnadel, S.; Überall, F.; Schennach, H.; Fuchs, D. Lavender oil suppresses indoleamine 2,3-dioxygenase activity in human PBMC. BMC Complement Altern Med 2014, 14, https://doi.org/10.1186/1472-6882-14-503.

55. Rai, V.K.; Sinha, P.; Yadav, K.S.; Shukla, A.; Saxena, A.; Bawankule, D.U.; Tandon, S.; Khan, F.; Chanotiya, C.S.; Yadav, N.P. Anti-psoriatic effect of Lavandula angustifolia essential oil and its major components linalool and linalyl acetate. $J$ Ethnopharmacol 2020, 261, https://doi.org/10.1016/j.jep.2020.113127.

56. Ross, S.A.; El-Keltawi, N.E.; Megalla, S.E. Antimicrobial activity of some Egyptian aromatic plants. Fitoterapia 1980, 51, 201-205.

57. Janssen, A.M.; Chin, N.L.; Scheffer, J.J.; Baerheim Svendsen, A. Screening for antimicrobial activity of some essential oils by the agar overlay technique. Pharm Weekbl Sci 1986, 8, 289-92, https://doi.org/10.1007/bf02280052. 
58. Gabbrielli, G.; Loggini, F, Cioni, P.L.; Giannaccini, B.; Mancuso, E. Activity of lavandino essential oil against non-tubercular opportunistic rapid growth mycobacteria. Pharmacol Res Commun 1988, 5, 37-40, https://doi.org/10.1016/s0031-6989(88)80836-1.

59. Larrondo, J.V.; Agut, M.; Calvo-Torras, M.A. Antimicrobial activity of essences from labiates. Microbios 1995, 82, 171-172.

60. Perrucci, S.; Cioni, P.L.; Flamini, G.; Morelli, I.; Macchioni, G. Acaricidal agents of natural origin against Psoroptes cuniculi. Parassitologia 1994, 36, 269-271.

61. Białoń, M.; Krzyśko-Łupicka, T.; Nowakowska-Bogdan, E.; Wieczorek, P.P. Chemical composition of two different Lavender essential oils and their effect on facial skin microbiota. Molecules 2019, 24, https://doi.org/10.3390/molecules24183270.

62. Adaszyńska-Skwirzyńska, M.; Szczerbińska, D. The antimicrobial activity of lavender essential oil (Lavandula angustifolia) and its influence on the production performance of broiler chickens. J Anim Physiol Anim Nutr (Berl) 2018, 102, 1020-1025, https://doi.org/10.1111/jpn.12907.

63. Ozkaraman, A.; Dügüm, Ö.; Özen Yılmaz, H.; Usta Yesilbalkan, Ö. Aromatherapy: The Effect of Lavender on Anxiety and Sleep Quality in Patients Treated With Chemotherapy. Clin J Oncol Nurs 2018, 22, 203210, https://doi.org/10.1188/18.CJON.203-210.

64. Xu, P.; Wang, K.; Lu, C.; Dong, L.; Gao, L.; Yan, M.; Aibai, S.; Liu, X. Protective effect of lavender oil on scopolamine induced cognitive deficits in mice and $\mathrm{H}_{2} \mathrm{O}_{2}$ induced cytotoxicity in PC12 cells. J Ethnopharmacol 2016, 193, 408-415, https://doi.org/10.1016/j.jep.2016.08.030.

65. Ellse, L.; Sands, B.; Burden, F.A.; Wall, R. Essential oils in the management of the donkey louse, Bovicola ocellatus. Equine Vet J 2016, 48, 285-289, https://doi.org/10.1111/evj.12431.

66. Dejaco, D.; Bocian-Sobkowska, J.; Szymanski, W.; Zacke, G.; Hockner, V.; Riechelmann, H. Tavipec in acute rhinosinusitis: a multi-centre, doubleblind, randomized, placebo-controlled, clinical trial. Rhinology 2019, 57, 367-374, https://doi.org/10.4193/Rhin19.089.

67. Kähler, C.; Derezinski, T.; Bocian-Sobkowska, J.; Keckeis, A.; Zacke, G. Spicae aetheroleum in uncomplicated acute bronchitis: a double-blind, randomised clinical trial. Wien Med Wochenschr 2019, 169,137-148, https://doi.org/10.1007/s10354-017-0612-0.

68. Lis-Balchin, M.; Hart, S. A preliminary study of the effect of essential oils on skeletal and smooth muscle in vitro. J Ethnopharmacol 1997, 58, 183-187, https://doi.org/10.1016/S0378-8741(97)00103-7.

69. Lis-Balchin, M.; Hart, S. Studies on the mode of action of the essential oil of lavender (Lavandula angustifolia P. Miller). Phytother Res 1999, 13, 540-542, https://doi.org/10.1002/(SICI)10991573(199909)13:6<540::AID-PTR523>3.0.CO;2-I.

70. Buchbauer, G.; Jirovetz, L.; Jäger, W.; Dietrich, H.; Plank, C. Aromatherapy: evidence for sedative effects of the essential oil after inhalation. $Z$ Naturforsch $C \quad J$ Biosci 1991, 46, 1067-1072, https://doi.org/10.1515/znc-1991-11-1223.

71. Park, K.H.; Kim, H.J.; Oh, B.; Seo, M.; Lee, E.; Ha, J. Evaluation of human electroencephalogram change for sensory effects of fragrance. Skin Res Technol 2019, 25, 526-531, https://doi.org/10.1111/srt.12682.

72. Das, S.; Gazdag, Z.; Szente, L.; Meggyes, M.; Horváth, G.; Lemli, B.; Kunsági-Máté, S.; Kuzma, M.; Köszegi, T. Antioxidant and antimicrobial properties of randomly methylated $\beta$ cyclodextrin-captured essential oils. Food Chem 2019, 278, 305-313, https://doi.org/10.1016/j.foodchem.2018.11.047.

73. Valladão, G.M.; Gallani, S.U.; Ikefuti, C.V.; da Cruz, C.; Levy-Pereira, N.; Rodrigues, M.V.; Pilarski, F. Essential oils to control ichthyophthiriasis in pacu, Piaractus mesopotamicus (Holmberg): special emphasis on treatment with Melaleuca alternifolia. J Fish Dis 2016, 39, 1143-1152, https://doi.org/10.1111/jfd.12447.

74. Yap, P.S.; Lim, S.H.; Hu, C.P.; Yiap, B.C. Combination of essential oils and antibiotics reduce antibiotic resistance in plasmid-conferred multidrug resistant bacteria. Phytomedicine 2013, 20, 710-713, https://doi.org/10.1016/j.phymed.2013.02.013.

75. Ogata K, Ataka K, Suzuki H, Yagi T, Okawa A, Fukumoto T, Zhang B, Nakata M, Yada T, Asakawa A. Lavender oil reduces depressive mood in healthy individuals and enhances the activity of single oxytocin neurons of the hypothalamus isolated from mice: a preliminary study. Evid Based Complement Alternat Med 2020, 2020, https://doi.org/10.1155/2020/5418586.

76. Delaveau, P.; Guillemain, J.; Narcisse, G.; Rousseau, A. Neuro-depressive properties of essential oil of lavender. C R Seances Soc Biol Fil 1989, 183, 342-348,

77. Umezu, T. Behavioral effects of plant-derived essential oils in the Geller type conflict test in mice. Jpn $J$ Pharmacol 2000, 83, 150-153, https://doi.org/10.1254/jjp.83.150.

78. Guillemain, J.; Rousseau, A.; Deleveau, P. Neurodepressive effects of essential oil of Lavandula angustifolia Mill. Ann Pharm Fr 1989, 47, 337-343.

79. Kasper, S.; Müller, W.E.; Volz, H.P.; Möller, H.J.; Koch, E.; Dienel, A. Silexan in anxiety disorders: Clinical data and pharmacological background. World J Biol Psychiatry 2018, 19, 412-420, https://doi.org/10.1080/15622975.2017.1331046.

80. Kasper, S.; Anghelescu, I.; Dienel, A. Efficacy of orally administered Silexan in patients with anxiety-related restlessness and disturbed sleep--A randomized, placebo-controlled trial. Eur Neuropsychopharmacol 2015, 25, 1960-1967, https://doi.org/10.1016/j.euroneuro.2015.07.024. 
81. Dunn, C.; Sleep, J.; Collett, D. Sensing an improvement: an experimental study to evaluate the use of aromatherapy, massage and periods of rest in an intensive care unit. J Adv Nurs 1995, 21, 34-40, https://doi.org/10.1046/j.1365-2648.1995.21010034.x.

82. Kang, H.J.; Nam, E.S.; Lee, Y.; Kim, M. How Strong is the Evidence for the Anxiolytic Efficacy of Lavender?: Systematic Review and Meta-analysis of Randomized Controlled Trials. Asian Nurs Res (Korean Soc Nurs Sci) 2019, 13, 295-305, https://doi.org/10.1016/j.anr.2019.11.003.

83. Bozkurt, P.; Vural, Ç. Effect of Lavender Oil Inhalation on Reducing Presurgical Anxiety in Orthognathic Surgery Patients. J Oral Maxillofac Sur 2019, 77, 2466.e1-2466.e7, https://doi.org/10.1016/j.joms.2019.08.022.

84. Seifritz, E.; Schläfke, S.; Holsboer-Trachsler, E. Beneficial effects of Silexan on sleep are mediated by its anxiolytic effect. J Psychiatr Res 2019, 115, 69-74, https://doi.org/10.1016/j.jpsychires.2019.04.013.

85. Genc, H.; Saritas, S. The effects of lavender oil on the anxiety and vital signs of benign prostatic hyperplasia patients in preoperative period. Explore (NY) 2020, 16, 116-122, https://doi.org/10.1016/j.explore.2019.07.008.

86. Zamanifar, S.; Bagheri-Saveh, M.I.; Nezakati, A.; Mohammadi, R.; Seidi, J. The effect of music therapy and aromatherapy with chamomile-lavender essential oil on the anxiety of clinical nurses: a randomized and double-blind clinical trial. J Med Life 2020, 13, 87-93.

87. Abbaszadeh, R.; Tabari, F.; Asadpour, A. The effect of lavender aroma on anxiety of patients having bone marrow biopsy. Asian Pac J Cancer Prev 2020, 21, 771-775,https://doi.org/10.31557/APJCP.2020.21.3.771.

88. Kasar, K.S.; Yildirim, Y.; Senuzun Aykar, F.; Uyar, M.; Sagin, F.G.; Atay, S. Effect of inhalation aromatherapy on pain, anxiety, comfort, and cortisol levels during trigger point injection. Holist Nurs Pract 2020, 34, 57-64, https://doi.org/10.1097/HNP.0000000000000350.

89. Guo, P.; Li, P.; Zhang, X.; Liu, N.; Wang, J.; Yang, S.; Yu, L.; Zhang, W. The effectiveness of aromatherapy on preoperative anxiety in adults: A systematic review and meta-analysis of randomized controlled trials. Int J Nurs Stud 2020, 111, https://doi.org/10.1016/j.ijnurstu.2020.103747.

90. Cornwell, S.; Dale, A. Lavender oil and perineal repair. Mod Midwife 1995, 5, 31-33.

91. Dale, A.; Cornwell, S. The role of lavender oil in relieving perineal discomfort following childbirth: a blind randomized clinical trial. J Adv Nurs 1994, 19, 89-96, https://doi.org/10.1111/j.1365-2648.1994.tb01056.x.

92. Koulivand, P.H.; Khaleghi Ghadiri, M.; Gorji, A. Lavender and the nervous system. Evid Based Complement Alternat Med 2013, 2013, https://doi.org/10.1155/2013/681304.

93. Soltani, R.; Soheilipour, S.; Hajhashemi, V.; Asghari, G.; Bagheri, M.; Molavi, M. Evaluation of the effect of aromatherapy with lavender essential oil on post-tonsillectomy pain in pediatric patients: a randomized controlled trial. Int J Pediatr Otorhinolaryngol 2013, 77, 1579-1581, https://doi.org/10.1016/j.ijporl.2013.07.014.

94. Koriem, K.M. Approach to pharmacological and clinical applications of Anisi aetheroleum. Asian Pac J Trop Biomed 2015, 5, 60-67, https://doi.org/10.1016/S2221-1691(15)30172-6.

95. Yıldırım, D.; Kocatepe, V.; Can, G.; Sulu, E.; Akış, H.; Şahin, G.; Aktay, E. The Effect of Lavender oil on sleep quality and vital signs in palliative care: a randomized clinical trial. Complement Med Res 2020, 12, 18, https://doi.org/10.1159/000507319.

96. Citlik Saritas, S.; Buyukbayram, Z.; Kaplan Serin, E.; Bilgic, Y. Effects of lavender oil intervention before endoscopic retrograde cholangiopancreatography on patients' vital signs, pain and anxiety: A randomized controlled study. Explore (NY) 2020, https://doi.org/10.1016/j.explore.2020.07.011.

97. Genç, F.; Karadağ, S.; Kılıç Akça, N.; Tan, M.; Cerit, D.The Effect of Aromatherapy on Sleep Quality and Fatigue Level of the Elderly: A Randomized Controlled Study. Holist Nurs Pract 2020, 34, 155-162, https://doi.org/10.1097/HNP.0000000000000385.

98. Iokawa, K.; Kohzuki, M.; Sone, T.; Ebihara, S. Effect of olfactory stimulation with essential oils on cardiovascular reactivity during the moving beans task in stroke patients with anxiety. Complement Ther Med 2018, 36, 20-24, https://doi.org/10.1016/j.ctim.2017.11.009.

99. Schaller, M.; Korting, H.C. Allergic airborne contact dermatitis from essential oils used in aromatherapy. Clin Exp Dermatol 1995, 20, 143-145, https://doi.org/10.1111/j.1365-2230.1995.tb02719.x.

100. Coulson, I.H.; Khan, A.S. Facial 'pillow' dermatitis due to lavender oil allergy. Contact Dermatitis 1999, 41, https://doi.org/10.1111/j.1600-0536.1999.tb06244.x.

101. Sugiura, M.; Hayakawa, R.; Kato, Y.; Sugiura, K.; Hashimoto, R. Results of patch testing with lavender oil in Japan. Contact Dermatitis 2000, 43, 157-1560, https://doi.org/10.1034/j.1600-0536.2000.043003157.x.

102. Hafez, E.S.E. Abortifacients in primitive societies and in experimental animal models. In: Contraceptive delivery systems. Hafez, E.S.E. ed. Lancaster, MTP Press, 1982.

103. San Martin. A.J. Medicinal plants in central Chile. Economic Botany 1983, 37, 216-227, https://doi.org/10.1007/BF02858788.

104. British herbal pharmacopoeia. Exeter, British Herbal Medicine Association, 1996. 